\title{
THE EMPIRICAL REVIEW ON THE WORKING ENVIRONMENT, MOTIVATION AND SOCIAL ATTRIBUTES ON CAREER PERFORMANCE IN OMAN
}

\author{
Salim Al Abdali \\ PhD Fellow \\ Faculty of Business and Accountancy \\ University of Selangor \\ Shah Alam, Malaysia \\ E-mail: salim.alabdali@gmail.com \\ Dr. Abul Bashar Bhuiyan \\ Associate Professor \\ Faculty of Business and Accountancy \\ University of Selangor \\ 40000 Shah Alam, Selangor Darul Ehsan, Malaysia \\ E-mail: bashariuk@gmail.com
}

\begin{abstract}
A strategically effective, hygienic, and healthy environment ensures bringing satisfaction among the employees while a drab, challenging, and competitive atmosphere leaves a seriously poor impact on the employees. At different times, employees are required to face a number of challenges, both operational and organizations where they are essentially expected to invest their best knowledge, skills, and experience, However, in a poorly developed atmosphere an employee basically refuses to invest his or her abilities which ultimately creates challenges for the organization. Therefore, the aim of the present study is to evaluate the effects of the working environment, motivation and social factors on career performance in Oman. The study used online empirical recourses by the name of working environment, motivation and social factors and career performance in different online database sources such as Google Scholars, Springer Link, Wiley, Science Direct, JSTOR, Emerald full text, Scopus, and EBSCO HOST, etc. The review findings summarized that maintaining a sophistically impressive working environment basically helps an organization to maintain a good image before the pool of skilled candidates in the market and helping it to acquire the best talents. Moreover, the study also concluded that the majority of the organizations across the globe are focusing on maintaining an effective working atmosphere to keep the employees more engaged to the organization than that of the other and it has a significant role in the comprehensive development of the organization. The findings of the study draw a guideline for future scope of empirical indebt study in the area of the career performance in Oman and the regions.
\end{abstract}

Keywords: Career Performance Attributes, Employee Performance \& Oman. 


\section{INTRODUCTION}

The careers of professionals are seeming to be seriously questioned whether private or public organizations in Oman. There are issue fundamentally frustrates the students, the country's future professionals, which demotivates them to invest their best skills, experiences and knowledge in the development of the organization to which they will be attached in the future. Most organizations in Oman seem to have ultimately failed to show their employees the scale of the business that they can scale to get the benefits and to show their skills, competencies and capabilities in the strategic development organization. In addition, organizations are not effectively equipped with all the necessary attribution facilities that most organizations around the world consider today. Likewise, there has been a significant drop in world oil prices in recent years, leading to a decline in the sultanate's general budget, an increase in the sultanate's public debt and a decline in its creditworthiness. There are salaries. The provision represents about $80 \%$ of the total expenditure of the Sultanate's general budget for the public sector. In particular, a clear reluctance of citizens to work in the private sector due to differences in salaries between graduates from different educational institutions in the sultanate and differences in pension systems.

Shehawy, Elbaz \& Agag (2018) insisted that an organization should pay close attention to recognizing and managing the work environment, both internally and externally, because when staff are confronted with the negative perception of a work environment, there are undoubtedly cases facing significant stress (Shehawy, Elbaz, \& Agag, 2018). Siriattakul, P., Saengchai, S., \& Jermsittiparsert, K. (2019) can be quoted that in order to talk about a work environment, one must essentially consider dealing with the tools, structure, system, conditions and processes within a workplace whose beneficial or adverse impact can be discouraged. very . performance of an individual (Siriattakul, Saengchai, \& Jermsittiparsert, 2019). The labour market is changing rapidly and the majority of employees working in this market are voluntary or non-volunteer (Sanyal \& Hisam, 2018). They are responsible for carrying out their responsibilities effectively. However, it is also true that in today's business environment, frequent job changes and insecurities are common among individuals. However, changing jobs can still be a difficult decision for individuals, given that such a decision can have crucial consequences for a person's career (Clarke, 2018; Rahman \& Bhuiyan, 2019; Rashid Al Hinai, Bhuiyan, \& Husin, 2021a, $2021 b, 2021 c)$. Unemployment and job security are two factors considered as stressors for the career of employees. This applies to all types of employees, regardless of their experience in the field. Some workers have a tendency to change jobs on a regular basis and it is not considered a good trait. It is believed that frequent job changes can damage the reputation of an organization's employees and leave a bad impression on their career (Yousef, 2017). Moreover, the unemployment is a harmful factor for employees and it is inversely related to their mental and physical health (Giragama \& Sooriyabandara, 2017). Hence, employees facing unemployment and job security related issues are expected to be emotionally exhausted and their physical wellbeing can be challenged as well (Shamsudin, Al-Badi, Bachkirov, \& Alshuaibi, 2016). Studies shows that many unemployed adults are the victims of depression and anxiety to a large extent, believed that the reason behind excess growth of cancer also is increased stress and anxiety, performed before highlighting factors like employee retention, employee turnover, job security, and the negative impacts of unemployment on the society and so on. However, it is a well-known fact that very few of those researchers highlight the case of frequent job changers and the impacts they leave on the society (Reardon, 2017). 
In such circumstance, present study summarized that the employees are required to face a number of challenges, both operational and organisations where they are essentially expected to invest their best knowledge, skills, and experience. However, in a poorly developed atmosphere an employee basically refuses to invest his or her abilities which ultimately creates challenges for the organisation. Professional career of a person is dedicatedly linked to the social factors which definitely works as a motivator to move ahead in the comprehensive development process. Therefore, the aim of the present study is to evaluate the effects of the working environment, motivation and social factors on career performance in Oman.

\section{Concept of Job Satisfaction}

\section{BACKGROUND OF THE STUDY}

Job satisfaction describe employee attitude towards their job responsibilities. It also mentioned the level of happiness attain by employees by performing their roles and responsibilities. It is favorable feeling for the business for attaining business objectives. It hinders the inward expression and attitude of employees towards their job roles and responsibilities. If the employee job satisfaction is high, then it reflects the fulfilment of psychological needs of employees. Job satisfaction is dispositional in nature. The examination of personal traits provides clear reflection in job satisfaction forecasting. Disposition also consider personal characteristics that influence the job satisfaction level and individual genetic makeup is determined as a factor. According to (Presbitero, Roxas, \& Chadee, 2016) the genetic makeup is one of the most important components of job satisfaction which is identified in monozygotic studies. The study concluded that the twin even reared at a distance from one to another and it tends to have similar level of satisfaction in the similar environment. It attributes that the genetic makeup is one of the important component of job satisfaction. However, (Alananzeh, Tarhini, \& Algudah, 2018) reflected in their studies that there is different level of job satisfaction which can be traced to differences in their disposition.

Work performance is considered to be a function of the work performance of an employee in terms of certain specific goals that comprises of well-explained standardized work explanation (Ogbari, Onasanya, Ogunnaike, \& Kehinde, 2018). Moreover, it presents those attitudes as well as performances that are handled by the workforce of an organization and also aimed towards the achievement of the objectives of an organization. Furthermore, (Niles \& Harris-Bowlsbey, 2005) explains job contentment to consist of credible attitudes that an individual experience in their work. Also, it is considered significant in terms of the achievement of company's objectives and even the behavior of individuals should be in relation to the objectives of an organization. Opposite to such strict developmental definition of work performance, it is recommended by (Nagele \& Awuor, 2018) that there is no need to completely pay heed to developmental aspects alone but even performance aspect should be considered as it is an attitude with an appraisal aspect. Moreover, this explanation is in accord with an assertive mechanism implemented for ascertaining the work performance through ratings given by the mentors as well as the other employees of the organization.

However, (Nagele \& Awuor, 2018) drive concentration towards this measurement in terms of providing an explanation for the performance discipline. Also, it is rigidly sustained that performance is an outcome of attitudes and not consequences. In the same way (Muduli, Verma, \& Datta, 2016) even depicts that the meaning of work performance should revolve around the concept of behavior and not around the consequences. This is because if the performance definition is based on any consequences then the same would drive the employees to find an 
easy-way out to generate results. Furthermore, such a short-cut also has the potential to produce an adverse effect on the concerned company due to the absence of some specific performance attitudes. Also, in this respect, (Muduli et al., 2016) specifies that performance is not the consequence of any particular behavior but it is considered to be a behavior on itself. In easy terms, performance consists of attitudes that an employee embraces and those that are recognizable.

(Mete, Sökmen, \& Biyik, 2016) concludes that smart employees are successful in handling their feelings to sustain a good state of mind for the purpose of producing effective work performance. Due to an increased potency of work performance at any organization, it is given immense consideration by the companies. Furthermore, the significance of work performance is based on the magnitude of tasks, view and objectives of an organization as well as those behaviors that are acceptable in a specific organization. (Motlou, Singh, \& Karodia, 2016) determines through the literature review of performance that there is a variance in between the additional responsibility as well as non-additional responsibility work functioning. Also, (Motlou et al., 2016) signifies that an additional responsibility work is termed as a company residential attitude. However, it is even suggested that there are two key categories of work performance known as work as well as theoretical functioning. Work performance also depicts the deployment of key tasks performed by each employee that has been officially framed in their work performance details. (Borman \& Motowidlo, 1997) depicts that such group of operations either supplements directly or even enable the output of commodities and services. Moreover, in an opposite direction theory-based performance consists of operations that are self-imposed and those that are not mentioned in the work description via which the employees can work towards enhancing their organizational environment. Also, such theory-based performance consists of the disposition to determine the tasks that needs to be performed also if it is not specifically mentioned in the work description. In addition, it even includes the task of transmitting optimistic attitudes towards the management, co-employees and the collaborators of the organization (Borman \& Motowidlo, 1997).

However, a theory-based performance as well as an organizational residency is supposition ally similar to one another (Edwards, Bell, Arthur, \& Decuir, 2008). But the literature of the two concepts had come out differently and it also states that there is little variation in between the two in relation to attitudes, reasons, consequences as well as perspectives (Organ, 1997). However, the scope for the success of an organization depends upon on their work as well as their theory-based operations (Conway, 1999). (Lim, 2008) asserted in their studies that the job satisfaction plays an important role for organizational success and personal interest. The study recognises the significance of job satisfaction phenomena where it can be interrupted that the behaviour of employee also impacted on work productivity. Therefore, the employees with high satisfaction have high productivity and also contribute towards the attainment of business objectives within the specific period of time. However, (Staw, 1986) state that the job satisfaction is inherent humanitarian value that encourages business productivity. However, job satisfaction also ensures that counterproductive work behavior is reduced. Additionally, job satisfaction has absence of generates lethargy and minimize the level of commitment among the employees. (Organ \& Ryan, 1995) reflected in their studies that the job satisfaction also improves citizenship behavior of employees. Further it also increases the retention level of employees and minimizes the recruitment costs of hiring new employees. Dissatisfaction among the employees directly impact on business performance due to decline in employee efforts to contribute towards attainment of business objective. (Gazioglu \& Tansel, 
2006) also mentioned in their studies that the employee turnover rate is also influenced by the job satisfaction of employees at workplace. The employees with low job satisfaction tend to increase the cost of training, recruitment, and selection.

\section{Relationship of Job satisfaction and performance}

Job satisfaction is the positive emotion result from the appraisal of job experience and fulfilment of employee needs. It implies that the job satisfaction can gain high performance whereas dissatisfied performance of employees yields low employee performance. On the other hand, employee observes behavior at workplace that effect on attaining business goals and objectives. It is important for the business to motivate the employees by fulfilling employee needs result into improvement in employee efforts to attain business objectives. The previous studies of organizational psychology and organizational behavior have shown that there is relationship between employee performance and job satisfaction. The relationship study is widely conducted since decade and interest in this area of study is growing. (Abualoush, Masa'deh, Bataineh, \& Alrowwad, 2018) has mentioned the relationship between job satisfaction and performance as Holy Grail and both depend on each other, gets influenced intermittently by each other. With the emergence of globalization and open market policies, organizations across the globe are hence required to work strategic and dynamic, and need to be complacent in their approaches so that it can help them in the corporate development process.

Additionally, it paves way for innovation and utmost creativeness that helps the organizations to grow and attain the competitive advantages in the market. Besides, the satisfied workforce actually helps an organization to grow and attain constructive development process that plays an effective role in the strategic growth process. Gone are those days when employees used to be considered as the service provider only, responsible for offering their services, and the organization was responsible for paying for their service. There were no strings attached between them. However, employees of today's market are considered as assets who play the most important role in the organizational growth process. The organizations do need to work in the strategic development of the workforce that originally helps in their growth process. Industrial/organizational psychology and interest henceforth remain integrated coherently between these two definite variables. The more the organizations act comprehensive in maintaining better consistency, the higher one can expect to attain the organizational growth that would technically help in the strategic growth process.

\section{METHODOLOGY}

As the aim of the present study is to evaluate the effects of the working environment, motivation and social factors on career performance in Oman. The methodology of this paper is done by conducting an extensive secondary data analysis. Therefore, the study used online empirical recourses by the name of working environment, motivation and social factors and career performance in different online database sources such as Google Scholars, Springer Link, Wiley, Science Direct, JSTOR, Emerald full text, Scopus, and EBSCO HOST, etc.

\section{Working environment}

\section{REVIEW FINDINGS}

Secured, convenient and appealing work environments can be produced only if the organizational surrounding is secured and sound. Sound organizational surrounding monitoring processes consists of sound monitoring, office lighting, air condition, provisions to meet the staff 
requirements, application of colours, work-place hygiene and offering other services needed by the staff such as toilets, wardrobe and religious places. In the context of improving employee's productivity, it is essential to explore the work-place surroundings, as it is in connection with encouragement which will lead to enhancing the all-round productivity of the employees.

As per (Shaya \& Khait, 2017), it is significant to pay attention to work surrounding because of two factors, first is the requirement of a comfortable workplace and employee's social connectivity beyond their organization. A convenient as well as sound work surrounding is managed by an organization on the basis of ethical, lawful and economical parameters. Ethically, the management of an organization maintains a secured, convenient and sound atmosphere that is created completely based on mankind. The management even conducts operations to generate useful and consistent work surroundings. Another purpose of the workplace should be to minimize incidents that can cause the employees and their families to suffer. As per (Osibanjo, Abiodun, \& Adeniji, 2014), tangible work surrounding is everything that surrounds an organization and that can influence the employees both immediately and circumstantially. Moreover, it is used by the employees to conduct their operations and also affects their ethical and emotional functions. It includes the air density, big space, sound, width and closeness affecting an individual's attitude. Also, it has the potential to put pressure on the employees that influences their productivity. Non-tangible work environment is all the conditions that exist in connection with the working relationship, including connection with the seniors as well as the juniors (Osibanjo et al., 2014).

Work surrounding can be another reason for enhancing the workforce productivity. Office convenience, presence of work assistance provisions, consistent work environment as well as a humble connection in between the workforce, senior and junior are the workplace surroundings that can lead the employees to give a higher level of performance (Raziq \& Maulabakhsh, 2015). Few factors for which an organization should pay heed to their work surrounding is that a convenient work-place surrounding will generate greater level of performance and also the absence of assisting provisions for work performance can lead to a considerable fall in the employee productivity rate (Osibanjo et al., 2014). Thus an effective office environment that assists the complete deployment of tasks has the potential to motivate greater productivity among the workforce both in terms of its magnitude as well as standard. (Samsudin, Isahak, \& Rampal, 2018) studies is related to the outcome of the exploration made by (Osibanjo et al., 2014), that work place should create an environment where employee's productivity can be enhanced.

In specific circumstances, the elements that finds out the elements that an employee is contended with work he does is because of the presence of an appropriate working condition (Mulyanto, 2015). Few of such explorations have accomplished themselves experimentally to justify that work surroundings can generate work contentment among the employees. Where there is sound working conditions, the employees feel delighted and satisfied in finishing their work.

\section{Motivation}

(Shoaib \& Baruch, 2019) debates that compensating includes all kinds of fiscal earnings, concrete provisions as well as the advantages which are received by the employees as a component of their working connections. (Taamneh, Alsaad, \& Elrehail, 2018) explain the term recompensation as that received by the workforce in return to the service they offered to an organization. Also, it is considered to be a kind of award provided by an organization to their staff. Such recompensation can be granted in terms of fiscal remuneration as well as non-fiscal 
remuneration. Compensating is considered to be a key component in manpower management of an organization. It is highly essential for the two teams, that is both for the staff as well as the organization. Moreover, it acts as a channel to draw interest of the employees, manage the employees and also encourage them to put in more efforts to improve their performance. Since remuneration is a condition due to which an individual want to work, it can also contribute towards being a great reason for staff contentment (Mabaso \& Dlamini, 2018). Moreover, the above concept is also backed up by (Hon \& Lu, 2015; Ismail, 2016) who depicts that both compensating and remunerating are difficult as well as multivariate elements of work contentment in senior educational organizations.

As per (Ukil, 2016), the compensating method used by organizations to pay their employees is affected by numerous elements. Such elements bring a provocation for every organization to find out about their decompensation principles for their employees. Offering compensation to the employees of both private as well as government organizations as per the proper principle under which the organization functions, is one technique to enhance the productivity of the employees. This technique is adopted because remuneration is considered to be an important reason that creates an impact of the level of staff contentment as well as the attitude of the workforce. To make it more clear, the greater is the remuneration offered to the staff, the more will be the work contentment level of the employees. Moving ahead, the greater the contentment rate of the employee, the greater will be their productivity. The explanation in the context of the connection between compensating and staff productivity is assisted by few experimental justifications that has been conducted by numerous explorers inclusive of both (Turner, 2018) and (Triguero Sánchez, Peña Vinces, \& Guillen, 2018). According to both their findings it was revealed that any means of compensating employees be it fiscal or non-fiscal will result in influencing workforce productivity.

Further experimental justifications states that a significant impact lies between the compensating process as well as work contentment. As per (Tatoglu, Glaister, \& Demirbag, 2016) remuneration and perks can be reason due to which the employees will attain greater job contentment level. At the same time, (Taamneh et al., 2018) also justifies that if good remuneration is offered the employees will tend to work more effectively. Also, (Saeed et al., 2013) states that remuneration conditions like pay, wage, appreciation, advancement, effective performance greatly influences the rate of contentment of the employees. Few research studies justify that work contentment can be produced by providing effective remuneration.

\section{Social Factors}

(Martin \& Thawabieh, 2018) mentioned in their studies that the job satisfaction level among the employees is impacted by the relationship with co-workers at workplace. Regardless of other factors the employee perceives that the positive relationship at workplace because it directly impacts on individual productivity at workplace. However, there are negative relations at workplace result into low level of job satisfaction and decline in business performance. (Motlou et al., 2016) support the research study that the social information prevailing in the business impact on job satisfaction among the employees. But the new employees at workplace can be morally corrupted at workplace during the socialization process. The employee needs to go through training and development program for employee motivation if they are around negative employees. In (Mete et al., 2016) perform the research study where training video if viewed by the participants who are under assembly line workers who gave review regarding the job. The study has shown that the participants who have watched the video so they enjoy working tasks 
whereas who has performed tasks without watching any video are not motivated to perform task. The research on social information processing theory shows that the social environment doesn't have any impact on employee attitude and behaviour at workplace.

(Khan \& Markauskaite, 2018) assert that the binary work responsibilities and family along with their clashes must be proportioned in their family and work expectations as well. To succeed in international business travel by balancing the stress, the social support gives the moderator factor. The experience they gathered and the opinions they had in the week before their journey, the on-trips in foreign and post-trip after return were asked them to remember. The study analyses that social support could have been a vital managing method against the exertions from family-work confrontation and by its effect on discerned pressure and insists the person to improve stable social support resources and networking at work as well as at home. This relativity would have importance as it would receive less pressure from family as well as the company. According to most researchers, who evaluated the features of business trips consider them to be pressure for the business traveller. (Khadhuri \& Eid, 2017) in his research study, represents two mentoring epitomes. The conventional perspective of mentoring is about a more experienced person to be considered a mentor and he pursues to be the epitome for a person obtaining less experience. That person is called the mentee. From the Department of Justice, a case study has been implemented to focus on that smooth mentoring initiative. Guided learning is another initiative. A co-worker who is more experienced implements the guided learning method to teach new skills to a less experienced employee. Another case study is represented to emphasize the application of guided learning. Mentoring connectivity happens in companies informally and obtains more time to construct career progression and psycho-social activities. (Kemp \& Zhao, 2016) had his research in the United States and asserted that companies that have a larger number of women employees obtain more policies of balancing work-life. The companies which recruit more women are supposed to have greater levels of productivity with higher numbers of policies. This assertion opposes the "adverse selection theory". As per this theory, the companies which have more lucrative policies would pursue those people who are needier of those policies.

(Kemp \& Zhao, 2016) in his research paper focuses on an important yet not discussed subject that is the impact of globalization and competitiveness the multinational companies face and the function that females can obtain to address those problems. Along with the growing requirement for scarce potentials and the confrontation for management quality, lady executives could have taken part to increase organizational functioning. He initiates barrier issues to the development of women executives and illustrates that to be a worldwide leader. The MNCs should develop programs that are action-oriented to inscribe gender and variable factors and the work-life apprehension of the modern society. (Waxin \& Bateman, 2016) in their analytical study, explains that social support at the workplace can incur from the company in a large firm, the immediate administrators as well as fellow employees. When support is pursued in this way, companies address and often avoid the supportive factors by their policies, advantages, tradition, and the career trails to gain a workable proportion between family and work life. An employee apart from his/her work can obtain social support from a spouse, siblings, parents, wards, expanded family as well as friends. Partners can support themselves in different ways such as income and own economic management. 


\section{Performance Appraisal}

There are various roles and responsibilities of an HR manager that must be taken into consideration hereby. It is true that many business organizations face challenges in sustaining in the extreme level of competitive business environment. However, it is not an issue if the employees of an organization are skilled and are performing their activities effectively (Aladwan, Bhanugopan, \& Fish, 2016). In case of public limited companies, it is often understood that greater level of competition is observed and they need to have proper plans to make sure that financial and HRM activities are at stable stage for those particular companies.

In this regard, the New Public Management (NPM) model must be taken into consideration. Under this particular model, government initiatives and activities must be reinvented to make sure that a particular market is more competitive in nature and there are lesser to no monopolies in any market. That is the way by which the government can make sure that all companies are getting equal opportunities and the consumers are also being charged moderately or in a cost effective manner.

It should also be noted that HR managers must be able to adopt a strategic approach to organizations so that any types of organizational issues and challenges are eliminated effectively. Apart from the HR managers, managers of different types and groups should also be able to take equal responsibilities to make sure that an organization will be free from issues (Ali, Nusair, Alani, Khan, \& Al Badi, 2017). It is necessary for organizational success. For any organization, the employees play a major role. They should be considered as the most essential asset of an organization. It is also true that skill development of the employees is necessary and accordingly, it is required that all employees are properly trained to make sure that the organizational requirements are fulfilled by them. According to (Agha, Azmi, \& Irfan, 2017), job training and performances of the employees of an organization are positively related to each other. (Subbarayalu \& Al Kuwaiti, 2018) thinks that job training, if performed carefully, can effectively create the basis of an organization. Therefore, the overall job role and performance of an employee can also be improved with the help of effective job training. (Pedrini, 2018) also has stated his opinions regarding the idea of human resource. According to him, for the growth of a business, the contributions of people are very high. Any organization cannot fulfil its goals and objectives without the presence of its skilled workforce. Every company requires the presence of some skilled employees who can effectively put efforts towards the organizational objectives in order to achieve long and short term goals. It is also a proven fact that by providing job trainings to the employees, an organization can reduce time and hence the numbers of mistakes can also be reduced accordingly. Therefore, the needs for training the employees are must for any company. According to (Waxin \& Bateman, 2016), trainings can help in improving the skills and knowledge of the employees and as a result, their productivity and confidence increase.

(Kemp \& Zhao, 2016) highlights a major factor hereby. According to him, if training and development is performed at a lower level, then the possibility of employees to migrate to another organization may become higher. That is a challenge for companies and this factor should be taken into consideration effectively. Similarly, in the higher levels, training effectively improves the satisfaction levels of employees and they feel more committed towards the company. As a result, the chances of migrating to another company decreases. Through training and development, the performances of employees improve and they start performing more promisingly. Hence, the risk of poor performances or mistakes can reduce. Additionally, the present business environment is largely competitive in nature and organizations must formulate strategies to sustain in this extreme level of competition. Hence, training the employees 
effectively will make sure that they are capable of working hard in these extreme situations of competition. (Al-Mahdy, Al-Harthi, \& Salah El-Din, 2016) has also suggested that to make sure that employees of an organization are skilled and productive, it is necessary to train them. According to (Ismail, 2016), trainings must be designed in such a way that organization's as well as employees' needs are fulfilled effectively. If the training is not designed as per employees' needs, many negative consequences can be observed.

\section{CONCLUSION AND RECOMMENDATIONS}

As the aim of the present study is to evaluate the effects of the working environment, motivation and social factors on career performance in Oman. The review findings summarized that maintaining a sophistically impressive working environment basically helps an organization to maintain a good image before the pool of skilled candidates in the market and helping it to acquire the best talents. Moreover, study found that the strategically effective, hygienic and healthy environment ensures bringing satisfaction among the employees while a drab, challenging and competitive atmosphere leaves seriously poor impact on the employees. In different times, employees are required to face a number of challenges, both operational and organisations where they are essentially expected to invest their best knowledge, skills, and experience, However, in a poorly developed atmosphere an employee basically refuses to invest his or her abilities which ultimately creates challenges for the organisation. Professional career of a person is dedicatedly linked to the social factors which definitely works as a motivator to move ahead in the comprehensive development process. Having an oblique working environment and with no social motivation basically a person seems to feel depressed and does not feel much interested to grow. A number of researchers henceforth have particularly concentrated on developing a healthy internal work culture that would typically ensure in the comprehensive organisational growth. The higher the employees are kept satisfied, the more they can be expected to employ their best skills and abilities in the development of the organisation. A number of researchers have found this out that maintaining a sophistically impressive working environment basically helps an organisation to maintain a good image before the pool of the skilled candidates in the market and helping it to acquire the best talents. Possibly this is the main reason that majority of the organisations across the globe are focusing on maintaining effective working atmosphere. Also, one should importantly address that the good working atmosphere keeps the employees more engaged to the organisation than that of the other and it has a significant role in the comprehensive development of the organisation. Moreover, the study also concluded that the majority of the organizations across the globe are focusing on maintaining an effective working atmosphere to keep the employees more engaged to the organization than that of the other and it has a significant role in the comprehensive development of the organization. The findings of the study draw a guideline for future scope of empirical indebt study in the area of the career performance in Oman and the regions.

\section{REFERENCES}

Abualoush, S., Masa'deh, R., Bataineh, K., \& Alrowwad, A. (2018). The role of knowledge management process and intellectual capital as intermediary variables between knowledge management infrastructure and organization performance. Interdisciplinary Journal of Information, Knowledge, and Management, 13, 279-309.

Agha, K., Azmi, F., \& Irfan, A. (2017). Work-life balance and job satisfaction: An empirical study focusing on higher education teachers in Oman. International Journal of Social Science and Humanity, 7(3), 164. 
Al-Mahdy, Y. F., Al-Harthi, A. S., \& Salah El-Din, N. S. (2016). Perceptions of school principals' servant leadership and their teachers' job satisfaction in Oman. Leadership and Policy in Schools, 15(4), 543-566.

Aladwan, K., Bhanugopan, R., \& Fish, A. (2016). What determines the work values of employees in a Middle Eastern cultural context? Evidences from Jordanian organizations. Employee Relations.

Alananzeh, O., Tarhini, A., \& Algudah, O. (2018). The effect of promotional mix on hotel performance during the political crisis in the Middle East. Journal of Hospitality and Tourism Technology.

Ali, Y., Nusair, M. M., Alani, F., Khan, F. R., \& Al Badi, L. (2017). Employment in the private sector in Oman: Sector-based approach for localization. Humanities \& Social Sciences Reviews, 5(1), 01-20.

Borman, W. C., \& Motowidlo, S. J. (1997). Task performance and contextual performance: The meaning for personnel selection research. Human performance, 10(2), 99-109.

Clarke, L. (2018). Mapping teacher status and career-long professional learning: The Place Model. Discourse: Studies in the Cultural Politics of Education, 39(1), 69-83.

Conway, J. M. (1999). Distinguishing contextual performance from task performance for managerial jobs. Journal of applied Psychology, 84(1), 3.

Edwards, B. D., Bell, S. T., Arthur, J., Winfred, \& Decuir, A. D. (2008). Relationships between facets of job satisfaction and task and contextual performance. Applied psychology, 57(3), 441-465.

Gazioglu, S., \& Tansel, A. (2006). Job satisfaction in Britain: individual and job related factors. Applied economics, 38(10), 1163-1171.

Giragama, K., \& Sooriyabandara, W. (2017). FACTORS AFFECTING THE CAREER DEVELOPMENT OF STAFF IN THE BANKING SECTOR: A CASE STUDY OF A PRIVATE BANK OF SRI LANKA. Paper presented at the Proceedings of the International Conference on Social Sciences.

Hon, A. H., \& Lu, L. (2015). Are we paid to be creative? The effect of compensation gap on creativity in an expatriate context. Journal of World Business, 50(1), 159-167.

Ismail, H. N. (2016). Training and organizational commitment: Exploring the moderating role of goal orientation in the Lebanese context. Human Resource Development International, 19(2), 152-177.

Kemp, L. J., \& Zhao, F. (2016). Influences of cultural orientations on Emirati women's careers. Personnel Review.

Khadhuri, A., \& Eid, J. (2017). An examination of the predictors of work engagement of the health care workforce in OMAN and the UAE.

Khan, M. S. H., \& Markauskaite, L. (2018). Technical and Vocational Teachers' Conceptions of ICT in the Workplace: bridging the gap between teaching and professional practice. Journal of Educational Computing Research, 56(7), 1099-1128.

Lim, S. (2008). Job satisfaction of information technology workers in academic libraries. Library \& Information Science Research, 30(2), 115-121.

Mabaso, C. M., \& Dlamini, B. I. (2018). Total rewards and its effects on organisational commitment in higher education institutions. SA Journal of Human Resource Management, 16, 8 . 
Martin, A., \& Thawabieh, F. A. (2018). The Effect of ISO 9001 to Oman Higher Education Operational Performance: Buraimi University College as a Case Study. International Journal of Applied Engineering Research, 13(6), 3939-3947.

Mete, E. S., Sökmen, A., \& Biyik, Y. (2016). The relationship between organizational commitment, organizational identification, person-organization fit and job satisfaction: A research on IT employees. International Review of Management and Business Research, 5(3), 870 .

Motlou, R. G., Singh, S., \& Karodia, A. M. (2016). An evaluation of the impact of job satisfaction on employee retention at Lonmin Rowland Shaft North West province. Kuwait Chapter of the Arabian Journal of Business and Management Review, 5(10), 15.

Muduli, A., Verma, S., \& Datta, S. K. (2016). High performance work system in India: Examining the role of employee engagement. Journal of Asia-Pacific Business, 17(2), 130-150.

Mulyanto, J. A. (2015). Influence of Discipline, Working Environment, Culture of Organization and Competence on Workers' Performance through Motivation, Job Satisfaction (Study in Regional Development Planning Board of Sukoharjo Regency). Regulation, 7(36).

Nagele, A. D., \& Awuor, E. (2018). Relationship between Transformational Leadership Style and Operational Performance of Hospitality Industry in Kenya: A Case Study of Star Rated Hotels in Nairobi County. Journal of Human Resource \& Leadership, 2(4), 37-58.

Niles, S. G., \& Harris-Bowlsbey, J. (2005). Career development interventions in the 21st century: Pearson/Merrill Prentice Hall Upper Saddle River, NJ.

Ogbari, M. E., Onasanya, Y. A., Ogunnaike, O. O., \& Kehinde, O. J. (2018). Talent management as a determinant of firm performance: A conceptual approach. Business \& Social Sciences Journal (BSSJ), 3(1), 21-32.

Organ, D. W. (1997). Organizational citizenship behavior: It's construct clean-up time. Human performance, 10(2), 85-97.

Organ, D. W., \& Ryan, K. (1995). A meta-analytic review of attitudinal and dispositional predictors of organizational citizenship behavior. Personnel psychology, 48(4), 775-802.

Osibanjo, A. O., Abiodun, A. J., \& Adeniji, A. A. (2014). Impact of job environment on job satisfaction \& commitment among Nigerian nurses. Journal of South Africa Business Research, 1-11.

Pedrini, M. (2018). Exploring the effect of gender diversity in MFIs during turbulent periods. The International Journal of Human Resource Management, 29(16), 2455-2481.

Presbitero, A., Roxas, B., \& Chadee, D. (2016). Looking beyond HRM practices in enhancing employee retention in BPOs: focus on employee-organisation value fit. The International Journal of Human Resource Management, 27(6), 635-652.

Rahman, M. Z., \& Bhuiyan, A. B. (2019). The Influencing Factors on the Effectiveness of Foundation Training Programs: A Case Study of the Health Cadre Service in Bangladesh. International Journal of Business and Management Future, 3(2), 13-21.

Rashid Al Hinai, M., Bhuiyan, A. B., \& Husin, N. A. (2021a). Does individual attributes matters on the employability readiness among engineering graduates of the higher education institutes in Oman.

Rashid Al Hinai, M., Bhuiyan, A. B., \& Husin, N. A. (2021b). Does social capital attributes effect the employability readiness among engineering graduates of the higher education institutes in Oman. 
Rashid Al Hinai, M., Bhuiyan, A. B., \& Husin, N. A. (2021c). The effects of human capital attributes on the employability readiness among engineering graduates of the higher education institutes in Oman.

Raziq, A., \& Maulabakhsh, R. (2015). Impact of working environment on job satisfaction. Procedia Economics and Finance, 23, 717-725.

Reardon, R. C. (2017). Enhancing self-help career planning using theory-based tools. Journal of Career Assessment, 25(4), 650-669.

Saeed, R., Mussawar, S., Lodhi, R. N., Iqbal, A., Nayab, H. H., \& Yaseen, S. (2013). Factors affecting the performance of employees at work place in the banking sector of Pakistan. Middle-East Journal of Scientific Research, 17(9), 1200-1208.

Samsudin, E. Z., Isahak, M., \& Rampal, S. (2018). The prevalence, risk factors and outcomes of workplace bullying among junior doctors: a systematic review. European Journal of Work and Organizational Psychology, 27(6), 700-718.

Sanyal, S., \& Hisam, M. W. (2018). Impact of training and development on the performance of employees-A comparative study on select banks in sultanate of Oman. International journal of scientific research and management, 6(03).

Shamsudin, F. M., Al-Badi, S. H., Bachkirov, A., \& Alshuaibi, A. S. (2016). PERCEIVED CAREER-RELATED PRACTICES AND KNOWLEDGE SHARING BEHAVIOUR: A PRELIMINARY STUDY IN OMAN. Asian Academy of Management Journal, 21.

Shaya, N., \& Khait, R. A. (2017). Feminizing leadership in the Middle East. Gender in Management: An International Journal.

Shehawy, Y. M., Elbaz, A., \& Agag, G. M. (2018). Factors affecting employees' job embeddedness in the Egyptian airline industry. Tourism Review.

Shoaib, S., \& Baruch, Y. (2019). Deviant behavior in a moderated-mediation framework of incentives, organizational justice perception, and reward expectancy. Journal of business ethics, 157(3), 617-633.

Siriattakul, P., Saengchai, S., \& Jermsittiparsert, K. (2019). The Mediating Role of Employee Engagement between Team and Co-worker Relation, Work Environment, Training and Development and Employee Performance. International Journal of Psychosocial Rehabilitation, 23(4).

Staw, B. M. (1986). Organizational psychology and the pursuit of the happy/productive worker. California Management Review, 28(4), 40-53.

Subbarayalu, A. V., \& Al Kuwaiti, A. (2018). Quality of work life of teaching staff working at a higher education institution in Saudi Arabia: A cross-sectional Study. Journal of Social Service Research.

Taamneh, A., Alsaad, A. K., \& Elrehail, H. (2018). HRM practices and the multifaceted nature of organization performance. EuroMed Journal of Business.

Tatoglu, E., Glaister, A. J., \& Demirbag, M. (2016). Talent management motives and practices in an emerging market: A comparison between MNEs and local firms. Journal of World Business, 51(2), 278-293.

Triguero Sánchez, R., Peña Vinces, J. d. C., \& Guillen, J. (2018). How to improve firm performance through employee diversity and organisational culture.

Turner, P. (2018). Whole Workforce Development. In Talent Management in Healthcare (pp. 189-220): Springer. 
Ukil, M. I. (2016). The impact of employee empowerment on employee satisfaction and service quality: Empirical evidence from financial enterprizes in Bangladesh. Verslas: teorija ir praktika, 17(2), 178-189.

Waxin, M. F., \& Bateman, R. E. (2016). Human resource management in the United Arab Emirates. In Handbook of human resource management in the Middle East: Edward Elgar Publishing.

Yousef, D. A. (2017). Organizational commitment, job satisfaction and attitudes toward organizational change: A study in the local government. International Journal of Public Administration, 40(1), 77-88.

\section{Copyrights}

Copyright for this article is retained by the author(s), with first publication rights granted to the journal. This is an open-access article distributed under the terms and conditions of the Creative Commons Attribution license (https://creativecommons.org/licenses/by/4.0) 